\title{
Historical Dynamics of the Development of the Corporate Governance
}

\author{
in Japan \\ Yuzuo Yao \\ The University of Manchester \\ Manchester, United Kingdom, M14 5TE \\ Tel: 44-75-0183-7999 E-mail: yaoyuzuobao@163.com
}

\begin{abstract}
Japan has developed a unique corporate governance structure over centuries, often in response to changes or crises in history. Recently, the loss and scandals have pushed the defects of the existing corporate governance mechanism into the spotlight. To answer whether the Japanese model will and should change, I need to understand how this system came into being and what has made a great impact on its development. Arguably, legal, political and cultural systems have promoted and shaped the Japanese model of corporate governance in particular ways. First, this essay finds that the Japanese corporate governance was historically heavily influenced by its legal origin, which has not been taken as a direct reason but an indirect reason. The courts in Civil Law countries could not resist governments' power and therefore gave politics opportunities to influence the development of the Japanese corporate governance directly. Second, the strong political forces favored financial institutions in corporate governance finance and employees during the war years and occupation but currently, these political influences are weak or have disappeared and central planning structure is discredited. It is time for Japan to make certain changes. Third, Japan has undertaken massive reforms of the corporate governance mechanism from the 1990s but it could not drop everything that is deeply rooted in its traditional culture. Hence, it is proposed that the keiretsu system and the lifetime employment should not disappear in the future albeit certain reforms are necessary in Japan.
\end{abstract}

Keywords: Collectivism, Corporate governance, Culture, Keiretsu, Legal origin, Long-term employment, Politics, Relationship banking system, Zaibatsu

\section{Introduction}

The corporate governance system in Japan has evolved over centuries, often in response to changes or crises in history. The first well-known change is World War II. Prior to the militarization of Japan in the 1930s, there were different patterns of corporate governance including broadly-held joint-stock companies, the state ownership of enterprise and a limited partnership holding company structure where family owners controlled diversified networks of publicly-quoted enterprises, run by professional management known as zaibasu. As Japan rebuilt its economy in the years following World War II, it developed a unique corporate governance structure. The Japanese model was quite distinct from the German model and the U.S. model and led to Japan becoming the second largest economy in the world by the 1980s. It was thus fashionable to ask whether other countries should be adopting Japan's model. Despite the Japanese model of corporate governance enjoyed a reputation for serving the needs in the 1980s, this ran into trouble in the early 1990s. The second important change that influenced the evolution of Japanese model of corporate governance was the economic crisis in the 1990s arising from globalization. Japan is no longer a developing country, so the old model no longer fits with environmental conditions and many of its strengths have become weaknesses in the face of global competition. The resulting loss and scandals push the defects of the existing corporate governance mechanism into the spotlight. To some observers, Japan should drop everything that characterized its unique corporate governance so that the Japanese corporate governance could become more international. The arguments advanced by these scholars and the debates they have generated are highly simulating but are largely unresolved.

To answer whether the Japanese model will and should change, I need to understand how this system came into being and what has made a great impact on its development. Arguably, there are several institutional factors behind the evolution, such as legal, political and cultural systems. These historical dynamics account for the emergence and evolution of the corporate governance in Japan over time. First, LLSV (Note 1)'s argument does a good of job of establishing a correlation between legal traditions and the development of the corporate governance regime, albeit their argument becomes questionable in light of the historical evolution of corporate governance (Note 2) in Japan. Second, Mark Roe argues most prominently for the importance of political factors in the emergence of distinctive corporate governance regimes. At last but not the least, the social embeddedness (i.e. culture) is a third factor in path dependence, which determines the development of the corporate governance. In short, these historical factors are constraints, which promote or shape the corporate governance in particular ways. 
This essay, in its brief compass, emphasizes the importance of history in the shaping of corporate governance. Section II begins by briefly introducing the main characteristics of corporate governance in Japan. Section III, Section IV and Section $\mathrm{V}$ form the heart of this essay. They sketch legal, political and cultural forces determining that particular type of corporate governance system in historical perspective respectively. Finally, the arguments on such issues will lead to a conclusion in Section VI.

\section{Characteristics of the Japanese Model of Corporate Governance}

According to Cadbury Report, corporate governance is the system by which companies are directed and controlled (Note 3). In other words, corporate governance deals with the relationships among the board of directors, management, shareholders and other stakeholders with respect to the control of corporations. Currently, the major new phenomenon is the new 'hybrid' pattern of corporate governance that involves a mix of elements from the 'old' Japanese model and 'new' more the Anglo-American practices (Note 4). The notable features of the symbiotic Japanese model can be listed as follows.

\section{A. Ownership Structure}

While the wider dispersion of ownership is characterized by the U.S. model, the Japanese model of corporate governance has been described as the keiretsu model (Note 5), because it contains a high degree of cross-shareholdings. In Japan, shareholdings are often not held by individuals or institutional investors who have no relationship to the company, but rather by dominant shareholders, such as main bank or a keiretsu partner which form part of a group of companies. Corporate governance in Japan is characterized by cross-shareholding, albeit there is a reduction from $50 \%$ of total market capitalization in 1990 to $20 \%$ in 2006 (Note 6)

Fiduciary duty of management exists (Note 7) in both the Japanese model and the U.S. model that involve different mechanisms. In theory, the board of directors represents the interests of the owners (shareholders) and is intended to control the management. The management is accountable to the general meeting of shareholders. In the U.S., the critical problem of the modern corporate governance is the principle-agent problem arising from the separation of ownership and control in that sometimes the managers may ignore the profits of the numerous and dispersed shareholders and breach their fiduciary duties. As a result, the owners of the company may lose money that they have invested at the hands of dishonest or reckless managers. In order to control this agency problem, the strong stock market and the takeover mechanism are used as instruments for aligning the benefits of shareholders with managerial interests. Conversely, Japan has developed an alternative governance mechanism. Since the ownership is concentrated in the hands of a keiretsu partner or main bank, who plays a more important role in monitoring the management, most companies in Japan are shield from takeovers and both ownerships and the control of the management are fused in practice.

\section{B. Relationship Banking System}

Banks in Japan can play a more prominent role in corporate governance than those in other countries-not only do they allocate the pool of available savings to the most productive projects (Note 8), but also monitor the management within corporations.

'In any economy banks serve as intermediaries in channeling savings into spending (investment and consumption). Indirect finance is ubiquitous across the world, although in the advanced capitalist countries such as the U.S., direct finance (stocks and bonds) plays a proportionately more important role in corporate finance.' (Note 9) Hence direct or indirect finance itself is nothing unique about Japan's heavy reliance on bank loans. But one key feature of the Japanese model of corporate governance is the concentration of shareholdings or loans from main banks that are characterized as long-term and stable creditors.

The other feature of the Japanese model is that the main bank system has supplemented Japanese-style management as an instrument of corporate governance. First, as noted, the Japanese model of corporate governance can mitigate the principle-agent problem by introducing relationship banking. This is because of the special nature of ties between firms and banks in Japan. A main bank has especially close ties to its customers through lending, shareholdings, and the board representation and other personal placement. This can give main banks relative easy access to the same information about the firm's opportunities upon which managers rely to make investment decisions. 'Several aspects of the keiretsu financing can help overcome problems with asymmetric information that contribute to adverse selection.' (Note 10) Thus, main banks can intervene in the management of firms, especially in times of financial distress. They can dispatch representatives to the board of directors and initiate restructuring activities.

\section{Employment System}

In Japan, the employment system is founded on two main elements: first, lifetime employment, in which workers spend their entire career at the same firm, slowly working their way up the ranks; second, seniority-based pay (age-based pay), which links wages to length of tenure rather than ability. According to Table 1, the Ministry of Finance survey finds that 
more than half of the sample companies maintain long-term employment and age-based pay (54\% in 2002). Compared to other models of corporate governance, lifetime employment and age-based pay have been viewed as two symbols of the unique employment system in Japan. Besides, most major firms have boards of 10-20 executives arranged in a strict hierarchy, based mainly on length of company service supplemented by personal achievement. At this level, the employees are involved with the management and therefore corporations cannot ignore the interests of employees.

Insert Table 1 Here

Source: Survey by Ministry of Finance, Policy Research Institute (PRI 2003)

All in all, the Japanese model of corporate governance is a set of economic, legal, political, and cultural institutions that protect the interests of shareholders, the creditors, and the employees as a whole. In this regard, the health and growth of the company is the corporation's first priority rather than the return of shareholders since the interests of other stakeholders such as banks and employees are not tied tightly to profits. Growth is the most important goal because it maximizes the welfare of shareholders (through capital gains), creditors (through loan security) and employees (through job security and wage growth). Have these characteristics of the current corporate governance been fostered by legal, political and cultural dynamics in the history of Japan? How and to what extent have historical changes influenced the Japanese model? These are the main questions addressed in the following parts of this essay.

\section{Legal Origins}

As noted, LLSV does a good job of establishing a correlation between the legal tradition and the characteristics of the corporate governance regime. They examine the variation of legal rules across countries deprived from different legal origins. The results are summarized in Table 2, which represents the percentage of countries in each legal family origin with respect to a number of indicators of investor rights. In conclusion, LLSV argue that there is a legal element to explain the differences in ownership concentration. The lack of minority shareholders' protection is the primary reason of the high degree of the concentration of ownership. If you protect shareholder better from expropriation, you will get more dispersed ownership. Generally, Common law countries have the strongest protection of shareholders, which leads to a dispersed ownership and the strong stock market. But the lack of minority shareholders' protection especially in Civil Law countries has been an obstacle to the emergence of dispersed ownership.

Insert Table 2 Here

Yet is the protection of minority shareholders the precondition to the emergence of dispersed ownership? Which is cause, which is effect? Japan is one of Civil Law countries. LLSV's argument becomes questionable in light of the historical evolution of corporate governance in Japan.

Examining the origins of corporate governance in Japan during the early nineteenth century, this essay finds that the lack of the protection of minority shareholders is not the primary reason. Prior to the militarization of Japan in the 1930s, there were three patterns of corporate governance. First, the dominant pattern involved broadly-held joint-stock companies, supported by highly liquid securities markets, and headed by professional management directing their companies in the interests of shareholders. Second, another pattern involved state ownership of enterprise where professional bureaucratic managers pursued public economic development goals. The third pattern is 'a European-style insider system with families controlling vast corporate empires called zaibatsu, which resembled some of the pyramidal empires found in continental Europe.'(Note 11) Interestingly, the Japanese corporate law did not contain as many measures to provide minority shareholders as LLSV identified (i.e. proxy votes, cumulative voting redemption rights for oppressed minorities and so on). The dispersed ownership structure was dominant while the Japanese law was not protective of minority shareholders. Hence, it is worth remembering that the protection of minority shareholders is not the primary cause or precondition to the dispersed ownership.

Admittedly, however, the Japanese corporate governance was historically heavily influenced by its legal origin that has not been taken as a direct reason but an indirect reason. It is pointed out that the courts of common law countries play a more prominent role by dealing with everyday situations as they occur, and that judges play an essential part in making law within reality on the basis of judiciary reasoning. More importantly, Coke justified the King 'does not have the privilege to personally decide a case at law.'(Note 12) In other words, courts could be of outstanding significance to resist governments' power in Common Law countries. With respect to the legal origin of Japan, judicial organs were restricted to apply rather than make law. Unlike the role of the courts of western countries, the courts in Japan could not have the authority to resist government's intervention. At this level, the Japanese civil origins gave politics opportunities to influence the development of the Japanese corporate governance directly.

\section{Politics}

In Japan, the development of corporate structure has been affected more closely by the politics form the early of the $20^{\text {th }}$ century into the $21^{\text {st }}$ century. The strong political forces favored financial institutions in corporate governance finance and employees during the war years and occupation but the pressure from the globalization especially in the 1990s 
called for the corporate governance reform in Japan. In the following parts, I will focus on the role of politics in the Japanese corporate governance by examining the development of relationship banking system and employment system.

\section{A. Political Influence on the Development of the Relationship Banking System}

Prior to the 1930s, the professional managers in most firms directed enterprises in shareholders' interests rather than the banks' interests and the ownership structure remained diversified and securities market far outweighed bank lending as a source for industrial finance.

In 1936, the military had the power to control the whole country and to bring down any cabinet it disapproved of. The military aimed to limit domestic competition and centralized capital allocation and investment decisions in the context of restricted capital and trade flows. 'The Temporary Funds Adjustment Act (IFAA), passed in September 1937, was the first important step. It sought to control long-term funds and preferentially allocate funds for war-related industries. Operationally this meant that each industry was classified by the Ministry of Finance (MOF) by its essentiality into one of three categories based on its importance to arm production, exports, and industrial expansion.' (Note 13) As firms came to reply on banks for funding, it became increasingly common for banks and firms to develop special relationships. There were zaibatsu banks with very close relationships to corporations that became the primary sources of corporate finance. As a result, bank lending outweighed the securities market. Generally, the decay of the securities market, the concentration of ownership and the main bank system emerged between the 1930s and 1950s from efforts by the Japanese state and strong incumbent banking and industrial firms (Note 14).

Centralized relationship banking system was also used for postwar recovery. After Japan's defeat, 'the occupation authorities forced the titular new Japanese government to pass a series of laws disbanding the zaibatsu, expropriating their family owners, outlawing holding companies, protecting minority stockholders, and establishing guidelines for accounting transparency, auditing and depreciation.' Therefore, the price of shares declined over the 1950s and 1960s, which created an initiative for relationship banks or keiretsu partners to buy more shares. As shown in Table 3, there was a sharp increase of the percentage of financial institutions that held the shares of corporations (from $9.9 \%$ in 1949 to $42.5 \%$ in 1988). The main banks played a more important role in making the inter-corporate shareholding as an effective defence against takeovers. Besides, main banks also monitor the management of corporations. What is distinctive is that once the relationship bank system was strategically controlled and micro-managed by the Japanese government (that is by the MOF which kept the Central Bank of Japan in its bailiwick), it would serve as a policy tool to channel funds into target industries (Note 15).

Insert Table 3 Here

The ongoing reforms, which started in the 1990s, aimed at an improvement in corporate governance in substance along the lines of globalization. Japan was no longer a developing country and central planning structure was discredited. As is shown by in Table 3, there is a decline of the percentage of financial institutions (from $42.5 \%$ in 1990 to $39.3 \%$ in 1996).

\section{B. Political Influence on the Development of the Employment System}

Similarly, the employment system of Japan has been influenced by politics in the history. With regard to other models, employees have no guarantee of permanent employment. The Lifetime employment system - employees can have their jobs until they retire - has been taken as the one feature of the Japanese model of corporate governance. After the World War II, 'lifetime employment has been a key institution, one developed to support social peace.' (Note 16) Japanese courts would penalize large corporation on the condition that they attempted to fire 'regular' employees, which brought enough peace to the corporations to allow production to go forward. At roughly the same time, as a consequence, enterprise managers were practically compelled, to manage their firms in the interests of employees who were acknowledged stakeholders. In some circumstances, managers followed employee's interests more than shareholders.

In globalization, the intensification of corporate competition of world market shares between governments tends to enhance the significance of policies strengthening efficiency. The employment system in Japan came under pressure from the 1990s, due to the globalization of financial markets and international distress in the Japanese economy. For one thing, 'Japan's average labor productivity in services fell from 88\% of the American level in 1993 to 84\% in 2003.' (Note 17) For anther, Japan also risks losing its edge in innovation since 'entrepreneurial start-ups account for only around $4 \%$ of firms in Japan, compared with $10 \%$ in Europe and over 14\% in America and Japan comes bottom in several rankings of entrepreneurship. Despite the might of its big exporters, Japan is also a laggard in globalization, with the lowest levels of foreign direct investment, imports and foreign workers in the OECD.'(Note 18) In recent years, as a result, performance-related pay has become a greater emphasis on meritocratic than seniority-based promotion in some Japanese corporations.

\section{Culture}

Facing rapid globalization, it becomes evident that the old Japanese model of corporate governance is challenged. 
Looking at the history of Japan, laws could not be the primary reason behind the change of the corporate governance but civil law origins gave politics opportunities to influence the development of the Japanese corporate governance directly. Currently, some political influences are weak or have disappeared and it is time for Japan to make certain changes. From the 1990s, Japan has undertaken massive reforms of the corporate governance mechanism but it could not drop everything that is deeply rooted in its traditional culture.

Culture is a set of attitudes, values and beliefs shared by unified group with a common language. The Japanese culture is a strong constraint, which promotes or shapes the Japanese corporate governance in a particular way. First, Japanese culture traditionally emphasized collectivism. The members emphasize in group-harmony very much (Note 19) and work together. Consequently, 'Japan's emergence from feudalism naturally has evolved into the keiretsu system of related party transaction, reinforced by cross-shareholdings.' (Note 20) Second, 'Japan is basically an egalitarian society, and Japanese businessmen have been traditionally beholden, with a strong sense of loyalty and obligation, to their own group and subordinates.' Employees in a large number of Japanese companies are respected and their jobs are secured. Japanese culture is something that is as difficult to change as the core personality of an individual. Thus, it is proposed that the keiretsu system lifetime employment should still exist in the future.

\section{Conclusion}

The corporate governance system in Japan has evolved over centuries. After World War II, the Japan rebuilt its economy and developed a unique corporate governance structure. The Japanese model was quite distinct from the German model and the U.S. model and led to Japan becoming the second largest economy in the world by the 1980s. It was thus fashionable to ask whether other countries should be adopting Japan's model. But the old model was challenged by the development of globalization and the economic crisis. Actually, the Japanese government has taken actions to impose corporate governance reforms in recent years.

Currently, there are three notable characteristics of the Japanese model of corporate governance. With regard to the ownership structure, first, shareholdings are often held by a main bank or a keiretsu partner in order to avoid the principle-agent problem. Second, relationship banks in Japan can play a more prominent role in the management within corporations. They can intervene in the management of firms especially in times of financial distress, dispatch representatives to the board of directors and initiate restructuring activities. Third, the employment system is founded on two main elements: first, lifetime employment, in which workers spend their entire career at the same firm, slowly working their way up the ranks; second, seniority-based pay (age-based pay), which links wages to length of tenure rather than ability. To protect the interests of shareholders, creditors and the employees as a whole, the Japanese model of corporate governance 'is focused on growth and market share.' (Note 21)

Arguably, these characteristics of the current corporate governance have been fostered by legal, political and cultural dynamics in the history of Japan. In the first place, this essay finds that the lack of the protection of minority shareholders is not the primary reason by examining the origins of corporate governance in Japan during the early twentieth century. Admittedly, however, the Japanese corporate governance was historically heavily influenced by its legal origin, which has not been taken as a direct reason but an indirect reason. The courts in Civil Law countries could not resist governments' power and therefore gave politics opportunities to influence the development of the Japanese corporate governance directly. In the second place, the strong political forces favored financial institutions in corporate governance finance and employees during the war years and occupation, but the pressure from the globalization especially in the 1990s called for the corporate governance reforms. Currently, some political influences are weak or have disappeared and central planning structure is discredited. It is time for Japan to make certain changes. In the third place, Japan has undertaken massive reforms of the corporate governance mechanism from the 1990s but it could not drop everything that is deeply rooted in its traditional culture. Hence, it is proposed that the keiretsu system and the lifetime employment should not disappear in the future albeit certain reforms are necessary in Japan.

In summary, all of these historical dynamics including legal, political and cultural systems have promoted and shaped the Japanese model of corporate governance in particular ways.

\section{References}

Antoin E. Murphy. (2004). 'Corporate Ownership in Finance-The Importance of History' (Released at the CEPR/ECGI/INSEAD/NBER/University of Alberta Joint Conference on The Evolution of Corporate Governance and Family Firms in 2004).

Dragneva-Lewers Rilka, (2009). 'Corporate Governance in Japan' (Lecture in 2009).

Dennis C. Mueller. (2006). 'Corporate Governance and Economic Performance’ 20 IRAE 623.

Gary Herrigel. (2006). 'Corporate Governance' in Geoffrey Jones and Jonathan Zeitlin (eds), Handbook of Business History (Oxford University Press, Oxford).

Hideaki Miyajima. (2008). 'The Performance Effects and Determinants of Corporate Governance Reform' in Masahiko 
Aoki, Gregory Jackson and Hideaki Miyajima (eds). Corporate Governance in Japan (Oxford University Press, Oxford).

John F. Northey, Leonard H. Leigh and David Goldberg. (1971). Introduction to Company Law (Butterworth, London). Julian Roche. (2005). Corporate Governance in Asia (Routledge, London and New York).

Klaus J. Hopt, Eddy Wymeersch, Hideki Kanda and Harald Baum. (2005). Corporate Governance in Context Corporations, States and Markets in Europe, Japan and the US (Oxford University Press, Oxford).

Kyoko Sakuma. (2001). 'Japan' in Klaus Gugler (eds), Corporate Governance and Economic Performance (Oxford University Press, Oxford).

La Porta, R, Lopez de Silanes F, Shleifer, A, and Vishny, R. (2000). 'Investor Protection and Corporate Governance' 58 JFE 3.

Magdi R. Iskander and Nadereh Chamlou. (2000). Corporate Governance: A Framework for Implementation (World Bank Group, Washington, D.C.).

Mark J. Roe. (2006). 'Legal Origins, Politics and Modern Stock Markets' 120 HLR 460.

Mark J. Roe. (2000). 'Political Preconditions to Separating Ownership from Corporate Control' 53 SLR 539.

Peggy M. Lee and Hugh M. O’Neill. (2003). ‘Ownership Structure and R\&D Investments of U.S. and Japanese Firms: Agency and Stewardship Perspectives’ 46 AMJ 212.

Peggy M. Lee. (2005). ‘A Comparison of Ownership Structures and Innovations of US and Japanese Firms' 26 MDE 39.

Rafael La Porta, Florencio Lopez-de-Silanes, Andrei Shleifer and Robert Vishiny. (2000). 'Investor Protection and Corporate Governance' 58 JFE 3.

Rafael La Porta, Florencio Lopez-de-Silanes, Andrei Shleifer and Robert Vishiny. (1999). 'Investor Protection: Origin, Consequences, Reform' (Working Paper No. W7428) <http://ssrn.com/abstract=227587>.

Ray Ball. (2005). 'Stakeholder toward a shareholder value model' in Christian Leuz, Dieter Pfaff, and Athony Hopwood (eds), The Economics and Politics of Accounting: International Perspectives on Research Trends, Policy, and Practice (Oxford University Press, Oxford).

Robert A.G. Monks and Nell Minow. (2001). Corporate Governance (2nd edn Blackwell Publishers Ltd, Oxford).

Robert H. Frank and Ben Bernanke. (2003). Principles of Macroeconomics (2nd edn Tsinghua University Press, Beijing).

Ronald J. Gilson \& Mark J. Roe. (1999). 'Lifetime Employment: Labor Peace and the Evolution of Japanese Corporate Governance' 99 COLUM. L. REV 508.

Sir Edward Coke. (2003). The Selected Writings of Sir Edward Coke (Liberal Fund, Indianapolis) No.5.

Takeo Hoshi and Anil K Kashyap. (2001). Corporate Financing and Governance in Japan: The Road to the Future (The MIT Press, Cambridge, Massachusetts, London, England).

Terutomo Ozawa. (2000). 'Japanese Firms in Deepening Integration: Evolving Corporate Governance' in Stephen S. Cohen and Gavin Boyd (eds), Corporate Governance and Globalization: Long Range Planning Issues (Edward Elgar Publishing Limited, Cheltenham, UK and Northampton, MA, USA).

The Economist, 'Japan's hybrid model of capitalism'. (2007)

$<$ http://www.economist.com/specialreports/displayStory.cfm?story_id=10169956>.

The committee on the Financial Aspects of Corporate Governance. (1993). 'Cadbury Report' (released in December 1992 and then applied to listed companies reporting their accounts after 30th June) $<$ http://www.ecgi.org/codes/documents/cadbury.pdf $>$.

Theodore M. Singelis, Harry C. Triandis, Dharm P. S. Bhawuk, Michele J. Gelfand. (1995). 'Horizontal and Vertical Dimensions of Individualism and Collectivism: A Theoretical and Measurement Refinement' 29 CR 240.

Toru Yoshikawa. (2008). 'Change and Continuity in Japanese Corporate Governance' 25 APJM 5.

Yasuhiro Arikawa and Hideaki Miyajima. (2008). 'Relationship Banks in Post-Bubble Japan: Coexistence of Soft-and Hard-Budget Constraints' in Masahiko Aoki, Gregory Jackson and Hideaki Miyajima (eds), Corporate Governance in Japan: Institutional Change and Organizational Diversity (Oxford University Press, Oxford).

\section{Notes}

Note 1. Rafael La Porta, Florencio Lopez-de-Silanes, Andrei Shleifer and Robert Vishiny focus on classification by 
legal origins to understand corporate governance. Please see Rafael La Porta, Florencio Lopez-de-Silanes, Andrei Shleifer and Robert Vishiny, 'Investor Protection and Corporate Governance' (2000) 58 JFE 3.

Note 2.Gary Herrigel, 'Corporate Governance' in Geoffrey Jones and Jonathan Zeitlin (eds), Handbook of Business History (Oxford University Press, Oxford 2006) 17.

Note 3. The committee on the Financial Aspects of Corporate Governance, 'Cadbury Report' (released in December 1992 and then applied to listed companies reporting their accounts after 30th June 1993) $<$ http://www.ecgi.org/codes/documents/cadbury.pdf $>$ accessed 5 November 2007.

Note 4. Yasuhiro Arikawa and Hideaki Miyajima, 'Relationship Banks in Post-Bubble Japan: Coexistence of Soft-and Hard-Budget Constraints' in Masahiko Aoki, Gregory Jackson and Hideaki Miyajima (eds), Corporate Governance in Japan: Institutional Change and Organizational Diversity (Oxford University Press, Oxford 2008) 39.

Note 5. Hideaki Miyajima, 'The Performance Effects and Determinants of Corporate Governance Reform' in Masahiko Aoki, Gregory Jackson and Hideaki Miyajima (eds), Corporate Governance in Japan. (Oxford University Press, Oxford 2008) 357.

Note 6. Dragneva-Lewers Rilka, 'Corporate Governance in Japan' (Lecture in 2009), 8.

Note 7. John F. Northey, Leonard H. Leigh and David Goldberg, Introduction to Company Law (Butterworth, London 1971).

Note 8. Robert H. Frank and Ben Bernanke, Principles of Macroeconomics (2nd edn Tsinghua University Press, Beijing 2003).

Note 9. Terutomo Ozawa, 'Japanese Firms in Deepening Integration: Evolving Corporate Governance' in Stephen S. Cohen and Gavin Boyd (eds), Corporate Governance and Globalization: Long Range Planning Issues (Edward Elgar Publishing Limited, Cheltenham, UK and Northampton, MA, USA 2000) 218.

Note 10. Takeo Hoshi and Anil K Kashyap, Corporate Financing and Governance in Japan: The Road to the Future (The MIT Press, Cambridge, Massachusetts, London, England 2001) 190.

Note 11. Dennis C. Mueller, 'Corporate Governance and Economic Performance' (2006) 20 IRAE 623, 628.

Note 12. Sir Edward Coke, The Selected Writings of Sir Edward Coke (Liberal Fund, Indianapolis 2003) No.5.

Note 13. Cf. Ashworth (n4) 54.

Note 14. Cf. Ashworth (n2) 20.

Note 15. Terutomo Ozawa, 'Japanese Firms in Deepening Integration: Evolving Corporate Governance' in Stephen S. Cohen and Gavin Boyd (eds), Corporate Governance and Globalization: Long Range Planning Issues (Edward Elgar Publishing Limited, Cheltenham, UK and Northampton, MA, USA 2000) 218.

Note 16. Ronald J. Gilson \& Mark J. Roe, 'Lifetime Employment: Labor Peace and the Evolution of Japanese Corporate Governance' (1999) 99 COLUM. L. REV, 508.

Note 17. The Economist, 'Japan's hybrid model of capitalism' (2007).

$<$ http://www.economist.com/specialreports/displayStory.cfm?story_id=10169956> accessed 15 April, 2009.

Note 18. Ibid.

Note 19. Theodore M. Singelis, Harry C. Triandis, Dharm P. S. Bhawuk, Michele J. Gelfand 'Horizontal and Vertical Dimensions of Individualism and Collectivism: A Theoretical and Measurement Refinement' (1995) 29 CR 240, 244.

Note 20. Ray Ball, 'Stakeholder toward a shareholder value model' in Christian Leuz, Dieter Pfaff, and Athony Hopwood (eds), The Economics and Politics of Accounting: International Perspectives on Research Trends, Policy, and Practice (Oxford University Press, Oxford 2005) 113.

Note 21. Robert A.G. Monks and Nell Minow, Corporate Governance (2nd edn Blackwell Publishers Ltd, Oxford 2001) 264. 
Table 1. Employment system

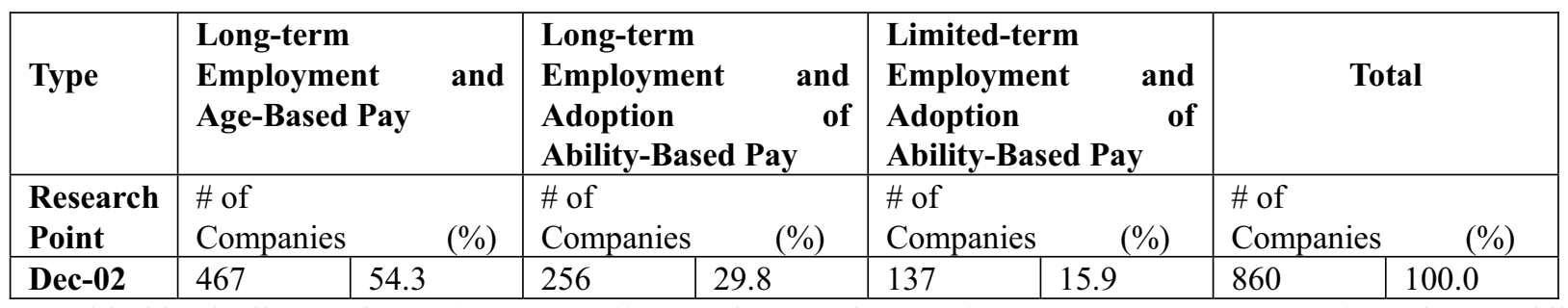

Note: Hideaki Miyajima, 'The Performance Effects and Determinants of Corporate Governance Reform' in Masahiko Aoki, Gregory Jackson and Hideaki Miyajima (eds), Corporate Governance in Japan (Oxford University Press, Oxford 2008) 357.

Table 2. Legal Origins

\begin{tabular}{|c|c|c|c|c|c|}
\hline \multicolumn{6}{|l|}{ Legal Origin } \\
\hline Variables & $\begin{array}{l}\text { Common Law } \\
\text { (18 countries) }\end{array}$ & $\begin{array}{l}\text { French Civil } \\
\text { Law } \\
\text { (21 Countries) } \\
\end{array}$ & $\begin{array}{l}\text { German Civil } \\
\text { Law } \\
(6 \text { countries }) \\
\end{array}$ & $\begin{array}{l}\text { Scandinavian } \\
\text { Civil Law } \\
(4 \text { countries }) \\
\end{array}$ & $\begin{array}{l}\text { World Average } \\
\text { (49 countries) }\end{array}$ \\
\hline $\begin{array}{l}\text { Anti-director rights } \\
\text { index }\end{array}$ & 4.00 & 2.33 & 2.33 & 3.00 & 3.00 \\
\hline Proxy by mail & $39 \%$ & $5 \%$ & $0 \%$ & $25 \%$ & $18 \%$ \\
\hline $\begin{array}{l}\text { Shares not blocked } \\
\text { before meeting }\end{array}$ & $100 \%$ & $57 \%$ & $17 \%$ & $100 \%$ & $71 \%$ \\
\hline Cumulative voting & $28 \%$ & $29 \%$ & $33 \%$ & $0 \%$ & $27 \%$ \\
\hline Oppressed minority & $94 \%$ & $29 \%$ & $50 \%$ & $0 \%$ & $53 \%$ \\
\hline $\begin{array}{l}\text { Preemptive right to } \\
\text { new issues }\end{array}$ & $44 \%$ & $62 \%$ & $33 \%$ & $75 \%$ & $53 \%$ \\
\hline $\begin{array}{l}\% \text { share of capital } \\
\text { to call and ESM } \leq \\
10 \%\end{array}$ & $94 \%$ & $52 \%$ & $0 \%$ & $0 \%$ & $78 \%$ \\
\hline
\end{tabular}

Note: Rafael La Porta, Florencio Lopez-de-Silanes, Andrei Shleifer and Robert Vishiny, 'Investor Protection: Origin, Consequences, Reform' (Working Paper No. W7428 1999) <http://ssrn.com/abstract=227587> accessed 15 April 2009.

Table 3. Share Distribution by Ownership Type in Japan (\%)

\begin{tabular}{|l|l|l|l|l|l|l|l|}
\hline Ownership type & $\mathbf{1 9 4 9}$ & $\mathbf{1 9 8 8}$ & $\mathbf{1 9 9 0}$ & $\mathbf{1 9 9 3}$ & $\mathbf{1 9 9 4}$ & $\mathbf{1 9 9 5}$ & $\mathbf{1 9 9 6}$ \\
\hline Financial institutions & 9.9 & 42.5 & 41.6 & 40.8 & 40.9 & 39.3 & 39.3 \\
\hline Private Companies & 5.6 & 24.9 & 25.2 & 23.9 & 23.8 & 23.6 & 23.8 \\
\hline Individuals & 69.1 & 22.4 & 23.1 & 23.7 & 23.5 & 23.6 & 23.6 \\
\hline Foreigners & n.a. & 4.0 & 4.2 & 6.7 & 7.4 & 9.4 & 9.8 \\
\hline Investment trust & n.a. & 3.1 & 3.6 & 3.0 & 2.6 & 2.1 & 2.0 \\
\hline Securities companies & 12.6 & 2.5 & 1.7 & 1.3 & 1.1 & 1.4 & 1.1 \\
\hline Government & 2.8 & 0.6 & 0.6 & 0.6 & 0.7 & 0.6 & 0.5 \\
\hline
\end{tabular}

Note: Kyoko Sakuma, 'Japan' in Klaus Gugler (eds), Corporate Governance and Economic Performance (Oxford University Press, Oxford 2001) 140. 